УДК 796.856:796.012.2-055.15

DOI https://doi.org/10.26661/2663-5925-2020-1-21

\title{
РОЗВИТОК КООРДИНАЦЙНИХ ЗДІБНОСТЕЙ У РІЗНИХ ВИДАХ ЄДИНОБОРСТВ
}

\author{
Товстопятко Ф. $\Phi$. \\ кандидат філософських наук, \\ доцент кафедри теорії та методики фізичної культури і спорту \\ Запорізький національний університет \\ вул. Жуковського, 66, Запоріжжя, Україна \\ orcid.org/0000-0002-4708-5916 \\ tovstopatkofedor@gmail.com \\ Тищенко В. О. \\ доктор наук із фізичного виховання і спорту, \\ професор кафедри теорії та методики фізичної культури і спорту \\ Запорізький національний університет \\ вул. Жуковського, 66, Запоріжжя, Україна \\ orcid.org/0000-0002-9540-9612 \\ valeritysh@gmail.com \\ Білозеров С. А. \\ студент магістратури II курсу \\ факультету фізичного виховання, здоров'я та туризму \\ Запорізький національний університет \\ вул. Жуковського, 66, Запоріжжя, Україна \\ orcid.org/0000-0002-3105-9481 \\ fortunateig@gmail.com \\ Тищенко Д. Г. \\ студент магістратури I курсу \\ факультету фізичного виховання, здоров'я та туризму \\ Запорізький національний університет \\ вул. Жуковського, 66, Запоріжжя, Украӥна \\ orcid.org/0000-0001-6201-4596 \\ handball.survey@gmail.com
}

Ключові слова: тхеквондо, панкратіон, тестування, хлопиі, спецііалізована базова підготовка.
Відповідно до концептуальних положень синергетичного підходу розв'язання завдань розвитку специфічних фізичних властивостей, які потрібні для успішного виконання професійних завдань, може бути здійснено і здійснюється на практиці через застосування різних засобів і методів контролю. Проте розвиток координаційних здібностей у різних видах єдиноборств, а саме у панкратіоні та тхеквондо, вивчено ще не досить, що й зумовило вибір теми нашого дослідження. Доведено, що завдяки навчально-тренувальним заняттям набагато поліпшуються гнучкість, витривалість, фізична міць (але 3 поміркованим акцентом на силі). Окрім того, тренування приводять до поліпшення зосередженості, керованого розслаблення, врівноваженості. Мета дослідження - здійснити порівняльний аналіз розвитку координаційних здібностей в єдиноборстві (на прикладі тхеквондо і панкратіону). Методи дослідження: теоретичний аналіз і узагальнення літературних джерел (проведено пошук інформації 
та з'ясовано обгрунтованість наукової проблематики дослідження); аналіз документальних матеріалів (вивчено структуру та зміст програми підготовки кваліфікованих спортсменів на етапі спеціалізованої базової підготовки в панкратіоні та тхеквондо); педагогічне тестування (встановлено показники координаційних здібностей спортсменів на етапі спеціалізованої базової підготовки в панкратіоні та тхеквондо); методи математичної статистики (використано для опрацювання емпіричних даних на етапах дослідження). Результати дослідження. Порівняння прикінцевих значень контрольної (спортсмени з тхеквондо) і експериментальної (спортсмени 3 панкратіону) груп вказало на високу статистичну значущість $(\mathrm{p}<0,001)$ отриманих показників за амплітудою рухів внутрішньо назад $(100,2 \pm 1,1 \mathrm{~cm}$ у контрольній групі та 110,3 $\pm 0,3$ см у експериментальній групі). Виявлено чималі позитивні зміни також за амплітудою рухів уперед. Достовірність

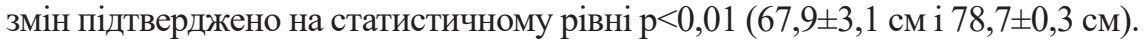
Висновки. Результати педагогічного дослідження вказали на покращення показників координаційних здібностей в експериментальній (спортсмени 3 панкратіону) і в контрольній (спортсмени 3 тхеквондо) групах у кінці дослідження. Але, на відміну від контрольної, статистично достовірні відмінності між початковими й кінцевими значеннями було виявлено за результатами всіх тестів в експериментальній групі. Засвідчено, що характер позитивних змін показників спортсменів із тхеквондо був суто тенденційним.

\title{
DEVELOPMENT OF COORDINATION ABILITIES IN DIFFERENT KINDS OF MARTIAL MARITIES
}

\author{
Tovstopiatko F. F. \\ PhD in Philology, \\ Associate Professor at the Department of Theory and Methods of Physical Culture and Sports \\ Zaporizhzhia National University \\ Zhukovskoho str., 66, Zaporizhzhia, Ukraine \\ orcid.org/0000-0002-4708-5916 \\ tovstopatkofedor@gmail.com \\ Tyshchenko V. O. \\ Doctor of Sciences in Physical Education and Sports, \\ Professor at the Department of Theory and Methods of Physical Culture and Sports \\ Zaporizhzhia National University \\ Zhukovskoho str., 66, Zaporizhzhia, Ukraine \\ orcid.org/0000-0002-9540-9612 \\ valeritysh@gmail.com
}

Bilozerov Ye. A.

Second-year Master's Student at the Faculty of Physical Education, Health and Tourism Zaporizhzhia National University

Zhukovskoho str., 66, Zaporizhzhia, Ukraine

fortunateig@gmail.com

Tyshchenko D. H.

First-year Master's Student at the Faculty of Physical Education, Health and Tourism

Zaporizhzhia National University

Zhukovskoho str., 66, Zaporizhzhia, Ukraine

handball.survey@gmail.com 
Key words: taekwondo, pankration, testing, boys, specialized basic training.
In accordance with the conceptual provisions of the synergetic approach, the solution of problems of development of specific physical properties which are necessary for the successful performance of professional tasks can be carried out and is carried out in practice by using of various means and methods of control. However, the development of coordination skills in various types of martial arts, namely in pankration and taekwondo, has not been studied enough, and this fact led to the choice of the topic of our study. It has been proven that flexibility, endurance, and physical strength are significantly improved due to training sessions (but with a moderate emphasis on strength). In addition, training improves concentration, controlled relaxation, balance. The purpose of the study: to make a comparative analysis of the development of coordination skills in martial arts (on the example of taekwondo and pankration). Research methods: theoretical analysis and generalization of literature sources (the search for information and clarification of the validity of scientific research issues has been done); analysis of documentary materials (the structure and content of the training program for qualified athletes at the stage of specialized basic training in pankration and taekwondo has been analyzed); pedagogical testing (indicators of coordination abilities of athletes at the stage of specialized basic training in pankration and taekwondo have been defined); methods of mathematical statistics (used to process empirical data at the stages of the study). Results of the research. Comparison of the final values of the control (taekwondo athletes) and experimental (pankration athletes) groups indicated a high statistical significance $(\mathrm{p}<0.001)$ of the obtained indicators on the amplitude of movements inward backward $(100.2 \pm 1.1 \mathrm{~cm}$ in the control group and $110.3 \pm 0.3 \mathrm{~cm}$ in the experimental group). Significant positive changes have been also detected in the amplitude of forward movements. Significance of changes has been confirmed at the statistical level $p<0,01(67.9 \pm 3.1 \mathrm{~cm}$ and $78.7 \pm 0.3 \mathrm{~cm})$. Conclusions. The results of the pedagogical study have indicated an improvement in coordination skills in the experimental (pankration athletes) and control (taekwondo athletes) groups at the end of the study. But in contrast to the control, statistically significant differences between the initial and final values have been found by the results of all tests in the experimental group. It is proved that the nature of positive changes in the performance of taekwondo athletes was extremely tendentious.
Вступ. Розвиток і вдосконалення координаційних здібностей в єдиноборстві науковцями розглядається як один із найпотужніших розділів підготовки спортсменів. Це зумовлено швидкоплинними змінами і швидкістю рухів під час змагань, екстремальним руховим режимом, який характеризується проявом максимальних зусиль i спеціальної витривалості, координаційної складності дій з елементами ризику [1]. Розвиток координаційних здібностей залежить від певних факторів, найважливіші 3 яких зображено на рисунку 1.

Особливе значення має вибір спрямованості педагогічних впливів і підбору засобів тренування i контролю. Потрібні більш масштабні дослідження фізичних і фізіологічних характеристик спортсменів із різних видів єдиноборств для розширення наявних знань [2; 3]. Засоби вимірювання активності руху - це, як правило, тест, тест діiі. Тестування є домінантними 3 погляду фізичного стану, тоді як прилади, що повинні вико- ристовуватися відповідно до досвіду й потреб, ігноруються з таких причин:

- відсутність стандартизованих форм тестування;

- недостатність часу на проведення випробувань і вимірювань;

- тестовий прилад не відповідає характеристикам спортсмена;

- тестовий прилад одноманітний;

- тестова форма не нагадує фактичну змагальну діяльність;

- обмежені можливості та інфраструктура впровадження тесту.

В останні роки в розвитку спортивних єдиноборств окреслюється тенденція до універсалізації, що призводить до утворення нових видів єдиноборств і перетворення вже наявних [4; 5]. Одним із таких видів справедливо $є$ панкратіон (поєдинок, у якому дозволяється застосовувати техніко-тактичні дії з боксу, дзюдо, самбо, вільної та греко-римської боротьби та інших видів єдино- 


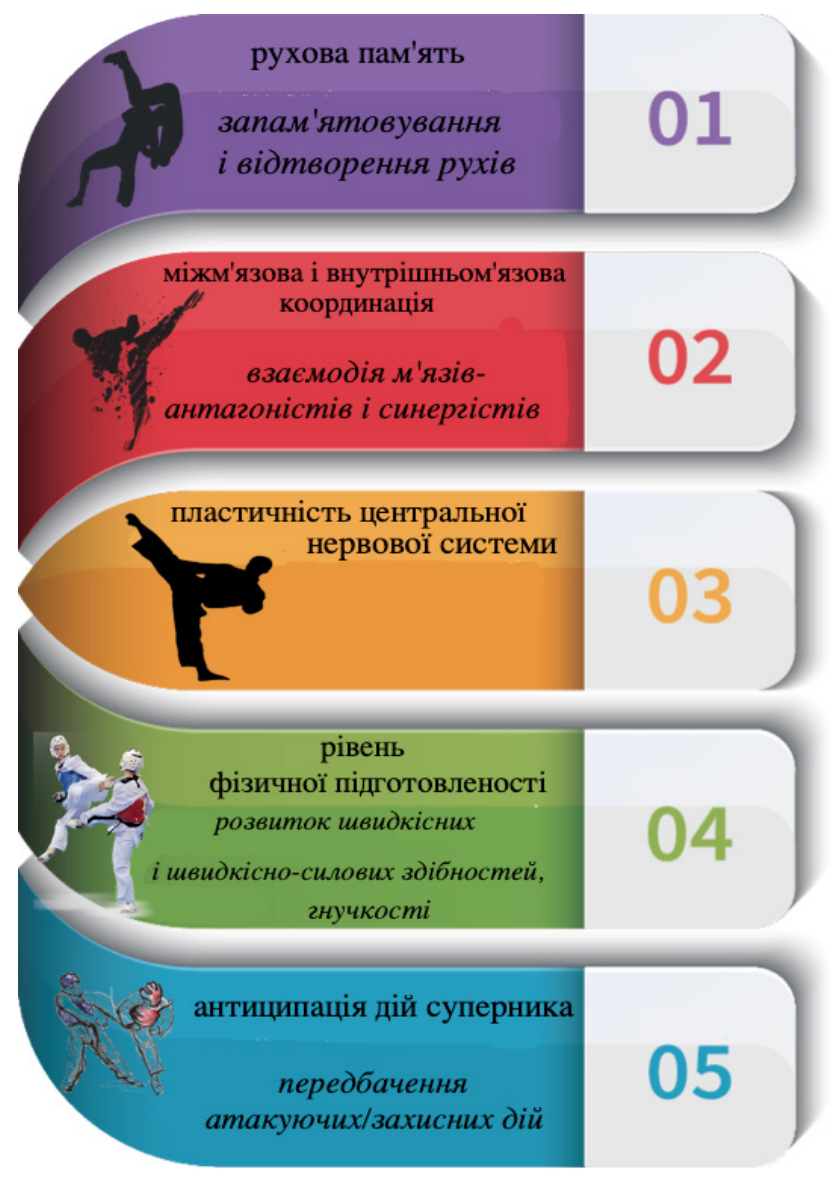

Рис. 1. Фактори розвитку координаційних здібностей в єдиноборстві

борств (різні удари руками й ногами до повного контакту)) [6].

Серед наявних наукових праць проблематиці панкратіону присвячено обмежену кількість публікацій. Привертають увагу в аспекті проблематики нашого дослідження роботи I. Наконечного, О. Томенка, В. Дзорданідіса, В. Кузьміна [7; 8]. Зокрема, на важливості правильної побудови навчально-тренувального процесу вказала низка авторів [9]. Також проаналізовано змагальну діяльність як дорослих, так і юних спортсменів [10; 11]. Питання спеціальної фізичної, техніко-тактичної підготовки та поведінкової саморегуляції знайшли відображення в роботах I. Наконечного [12].

Вищеназвані дослідження, незважаючи на відмінність підходів, становлять інтерес перш за все в плані використовуваних методів. У цьому контексті видається вельми актуальним аналіз розвитку координаційних здібностей у спортсменів iз тхеквондо i панкратіону. Теоретичний аналіз літератури дає змогу виділити саме цей перспективний напрям розроблення, що й спонукало нас до проведення дослідження.
Мета дослідження - здійснити порівняльний аналіз розвитку координаційних здібностей в єдиноборстві (на прикладі тхеквондо і панкратіону).

Об'єкт дослідження - система підготовки в єдиноборстві.

Предмет дослідження - показники координаційних здібностей в єдиноборстві (на прикладі тхеквондо і панкратіону).

Відповідно до мети дослідження в роботі було поставлено такі завдання:

1. Здійснити порівняльний аналіз вихідних значень показників координаційних здібностей спортсменів із тхеквондо і панкратіону.

2. Дослідити динаміку показників координаційних здібностей спортсменів із тхеквондо і панкратіону.

3. Провести порівняльний аналіз динаміки показників координаційних здібностей спортсменів із тхеквондо і панкратіону.

Методи дослідження: аналіз і узагальнення даних науково-методичної літератури, тестування, педагогічні спостереження, методи математичної статистики.

Застосовано методики й тести, які, на нашу думку, є найбільш інформативними та відображають характеристики, що впливають на ефективність навчально-тренувальної діяльності в єдиноборстві, а саме:

1. "Y Balance Test Station" (контроль координації рухів), см - це тест у динамічному режимі, що виконується в стійці на одній нозі (рис. 2) та висуває підвищені вимоги до силових і координаційних здібностей, гнучкості, а також пропріоцепції.

Ця методика використовується для контролю координаційних здібностей, симетрії в рухах, а також визначає рівень ризику отримання травми нижніх кінцівок.

Тест передбачає оцінювання амплітуди рухів у трьох напрямках: уперед, внутрішньо назад, латерально назад.

Утримуючи рівновагу на одній нозі, продемонструвати максимально можливу амплітуду руху (гнучкості) іншою ногою, плавно рухаючи вимірювальну платформу. Випробуваний робить по три спроби у всіх напрямках кожною ногою (босоніж). Результат оцінюється в сантиметрах.

Спроба не зараховується у разі, якщо випробовуваний торкається ногою підлоги або поштовховим рухом переміщує платформу.

2. Тест на стато-динамічну рівновагу (контроль можливостей підтримувати рівновагу тіла (баланс)). Простим способом контролю здатності до підтримання рівноваги тіла $є$ розроблений у Північній Америці тест на стато-динамічну рівновагу. Для проведення тесту потрібна наявність секундоміра й балансувальної дошки (рис. 3). 


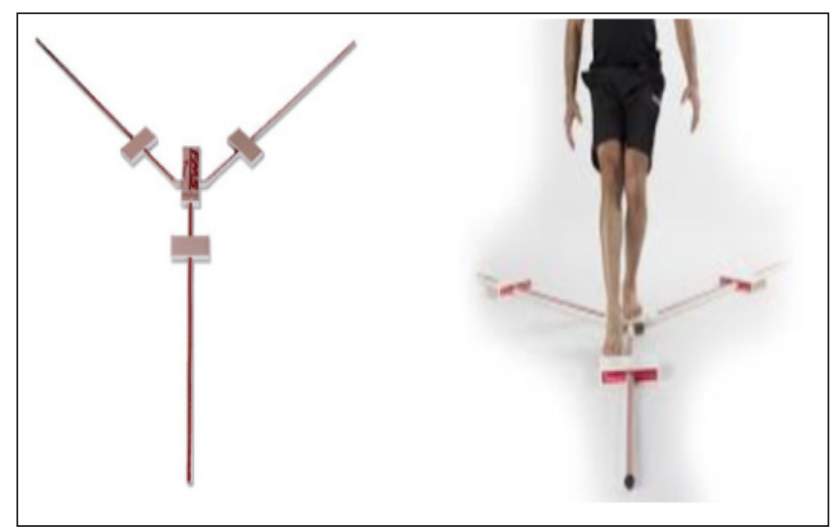

Рис. 2. Зображення "Y Balance Test Station"

$€$ велика кількість їхніх різновидів, хоча принцип дії всюди однаковий. Незалежно від того, балансувальна дошка якої фірми використовуватиметься, головне, щоб під час повторних досліджень використовувалася одна й та сама.

Початкове положення: випробуваний стає на балансувальну дошку. Ноги дозволяється ставити в будь-яке зручне становище. Завдання утримувати баланс протягом 30 секунд із мінімальною кількістю торкань майданчика. Секундомір запускається за командою «Старт!», за готовністю випробуваного.

Вимірювання. Оцінюється кількість торкань майданчика за 30 секунд.

Таблиця 1

Оціночна шкала тесту на стато-динамічну рівновагу, к-сть торкань

\begin{tabular}{|c|c|c|c|c|}
\hline \multicolumn{5}{|c|}{ Рівень підготовленості } \\
\hline $\begin{array}{c}\text { Дуже } \\
\text { низький }\end{array}$ & Низький & Середній & Високий & $\begin{array}{c}\text { Дуже } \\
\text { високий }\end{array}$ \\
\hline $\begin{array}{c}14 \\
\text { в більше }\end{array}$ & $9-13$ & $5-8$ & $1-4$ & 0 \\
\hline
\end{tabular}

3. "Hexagonal Obstacle Test" (відображає абсолютний показник здатності до перебудови рухових дій і швидкість).

Для проведення тесту необхідна наявність секундоміра та позначений на підлозі боковий шестикутник розміром у 66 см (рис. 4).

Виконання. Спортсмен стоїть по середині шестикутника перед лінією А. За командою запускається секундомір, i він стрибає обома ногами через лінію В і назад у середину, потім - через лінію $\mathrm{C}$ і назад у середину, потім лінію D і так далі. Коли спортсмен перестрибнув через лінію А і повернувся в середину, це вважається одним колом. Потрібно зробити три кола (зробити 36 стрибків) за найкоротший термін. Після завершення трьох кіл годинник зупиняється, і час записується.

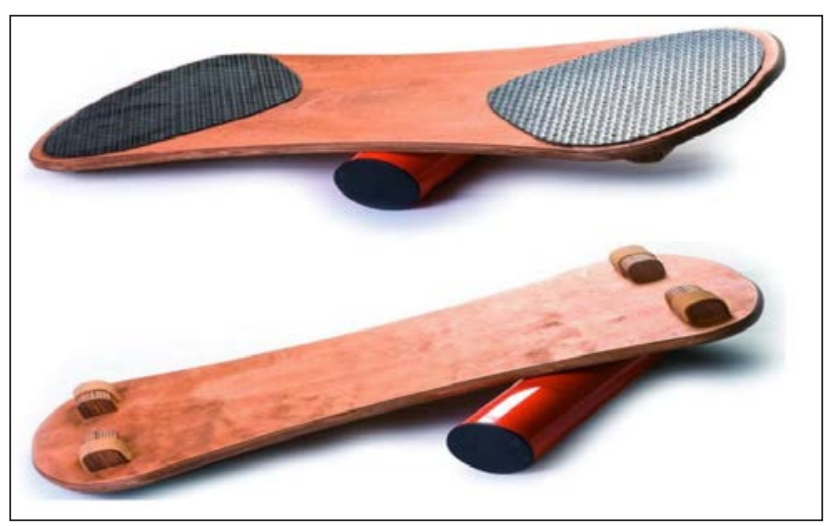

Рис. 3. Балансувальна дошка

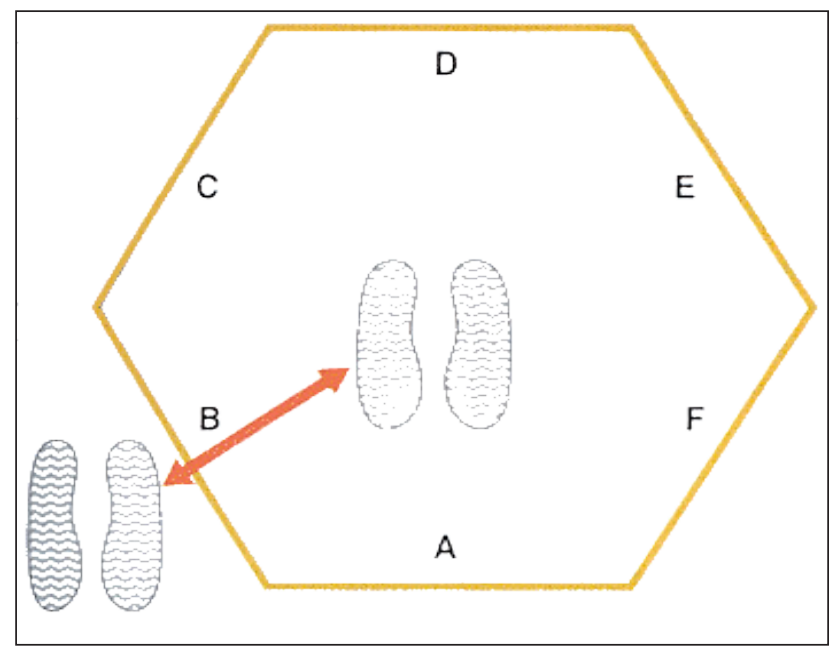

\section{Рис. 4. Схема виконання тесту "Hexagonal Obstacle Test"}

Протягом усього тесту спортсмен повинен стояти перед лінією А. Якщо перестрибнули не ту лінію або приземлилися на ній, тест потрібно повторити.

Отриманий результат фіксується в секундах (табл. 2).

\section{Таблиця 2}

\section{Шкала оцінок результатів тесту} "Hexagonal Obstacle Test"

\begin{tabular}{|c|c|c|c|c|}
\hline \multicolumn{5}{|c|}{ Рівень підготовленості } \\
\hline Низький & $\begin{array}{c}\text { Нижче за } \\
\text { середній }\end{array}$ & Середній & $\begin{array}{c}\text { Вище за } \\
\text { середній }\end{array}$ & Високий \\
\hline$>17,8$ с & $15,6-17,8$ c & $13,4-15,5$ c & $11,2-13,3$ c & $<11,2$ c \\
\hline
\end{tabular}

Організація дослідження. У дослідженні взяли участь 27 спортсменів групи спеціальної базової підготовки. Секцію 3 панкратіону (експериментальна група - ЕГ) відвідували - 15 , із тхеквондо (контрольна група - КГ) - 12 осіб. Процес підготовки здійснювався за навчальними програмами для дитячо-юнацьких спортивних шкіл із панкра- 
тіону та тхеквондо $[13 ; 14]$. Режим навчально-тренувальної роботи в дитячо-юнацьких спортивних школах грунтується на потрібних для досягнення високих результатів обсягах тренувальних навантажень, загальних i специфічних принципах спортивного тренування, особливо на принципах поступовості їх зростання та оптимальних термінах досягнення високої спортивної майстерності.

Виклад основного матеріалу дослідження. Вихідний рівень показників координаційних здібностей засвідчив відсутність вірогідних відмінностей у спортсменів контрольної та експериментальної груп за всіма тестами. Проведення такого аналізу є необхідною умовою для об’єктивної інтерпретації результатів дослідження.

Для оцінки впливу секційних занять із тхеквондо і панкратіону на показники координаційних здібностей проведено аналіз їхньої динаміки. Порівнювалися відповідні дані, які було зафіксовано на початку і в кінці дослідження (табл. 3 і 4).

Отже, за тестом "Y Balance Test Station", який оцінює амплітуду рухів за трьома напрямками, протягом дослідження визначено таке (табл. 3). $\mathrm{y}$ контрольній групі статистично достовірних змін у спортсменів із тхеквондо не зареєстровано $(\mathrm{p}>0,05)$. Можна говорити тільки про тенденцію до їх підвищення. Різниця перебувала на рівні статистичної похибки як на початку, так і наприкінці дослідження. Поліпшення після закінчення дослідження на 5,93 \% від вихідного рівня зафіксовано за амплітудою рухів уперед; на 2,66 \% - за амплітудою рухів внутрішньо назад; на 2,27 \% - за амплітудою рухів латерально назад.
Підсумки статистичного аналізу даних, здібності до координації рухів за тестом "Y Balance Test Station" хлопців експериментальної групи свідчать про їхнє достовірне (від $\mathrm{p}<0,05$ до $\mathrm{p}<0,001)$ поліпшення після закінчення дослідження. Зокрема, за амплітудою рухів уперед констатовано відносний приріст на 18,52 \% $(\mathrm{p}<0,01)$; за амплітудою рухів внутрішньо назад на $11,26 \%(\mathrm{p}<0,001)$; за амплітудою рухів латерально назад - на $12,5 \%(\mathrm{p}<0,05)$ від вихідного рівня (табл. 3).

Порівняння прикінцевих значень контрольної та експериментальної груп вказало на високу статистичну значущість $(\mathrm{p}<0,001)$ отриманих показників за амплітудою рухів внутрішньо назад $(100,2 \pm 1,1$ см у контрольній групі та $110,3 \pm 0,3$ см в експериментальній групі) за відносного приросту на $10,08 \%$. Виявлено чималі позитивні зміни також за амплітудою рухів уперед. Достовірність змін підтверджено на статистичному рівні $\mathrm{p}<0,01$ $(67,9 \pm 3,1$ см і $78,7 \pm 0,3$ см) за відносного приросту на $15,91 \%$. Також відбулася достовірна різниця $(\mathrm{p}<0,05)$ показників за амплітудою рухів латерально назад на $8,57 \%$ (табл. 3).

Динаміка показників координаційних здібностей спортсменів контрольної та експериментальної груп протягом дослідження показала на поліпшення результатів. Водночас зауважимо, що достовірних змін показників у спортсменів контрольної групи протягом дослідження зареєстровано не було. Засвідчено, що характер позитивних змін показників був суто тенденційним, тобто з відсутністю статистично достовірних відмінностей. Поліпшилися показники за тестом на

Таблиця 3

\section{Динаміка показників координаційних здібностей спортсменів контрольної та експериментальної груп протягом дослідження}

\begin{tabular}{|c|c|c|c|c|c|c|c|c|c|c|c|c|}
\hline Показники & \multicolumn{2}{|c|}{ КГп } & \multicolumn{2}{|c|}{ КГк } & $\mathbf{t}_{1}$ & \multicolumn{2}{|c|}{ ЕГп } & \multicolumn{2}{|c|}{ ЕГк } & $\mathbf{t}_{2}$ & $\mathbf{t}_{3}$ & $\mathbf{t}_{4}$ \\
\hline $\begin{array}{l}\text { "Y Balance Test Station" } \\
\text { (вперед), см }\end{array}$ & 64,1 & 4,3 & 67,9 & 3,1 & 0,7 & 66,4 & 3,5 & 78,7 & 0,3 & $3,5^{* *}$ & 0,4 & $3,4^{*}$ \\
\hline $\begin{array}{l}\text { "Y Balance Test Station" } \\
\text { (внутрішньо назад), см }\end{array}$ & 97,6 & 3,4 & 100,2 & 1,1 & 0,7 & 99,1 & 2,3 & 110,3 & 0,3 & $4,8 * * *$ & 0,4 & $8,8^{*}$ \\
\hline $\begin{array}{l}\text { "Y Balanc } \\
\text { (латеральғ }\end{array}$ & 01,5 & 4,6 & 103,8 & 2,1 & 0,5 & 100,2 & 4,3 & 112,7 & 1,2 & $2,8^{*}$ & 0,2 & $37=$ \\
\hline $\begin{array}{l}\text { Тест на стато } \\
\text { рівновагу, к-с }\end{array}$ & 11,8 & 6,8 & 21, & 3,2 & 1,24 & 10,9 & 4,1 & 29,8 & 1,1 & $4,45^{* * *}$ & 0,11 & 2,5 \\
\hline "Hexagonal Obstacle Test", c & 17,2 & 2,2 & 15,7 & 1,2 & 0,60 & 17,4 & 2,3 & 12,2 & 0,5 & $2,21^{*}$ & 0,06 & $2,69^{*}$ \\
\hline
\end{tabular}

Примітка: КГп-початкові показники контрольної групи; КГк-кінцеві показники контрольної групи; ЕГn- початкові показники експериментальної групи; ЕГк-кінцеві показники експериментальної групи;

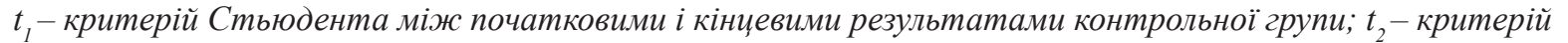
Стьюдента між початковими і кінцевими результатами експериментальної групи; $t_{3}-$ критерій Стьюдента між початковими результатами контрольної й експериментальної групами; $t_{4}$ - критерій Стьюдента між кінцевими результатами контрольної й експериментальної групами; * - різниця між показниками вірогідна за $p<0,05$; ** - різниця між показниками вірогідна за $p<0,01$; *** - різниця між показниками вірогідна за $p<0,001$ 
стато-динамічну рівновагу на 78,81\%; "Hexagonal Obstacle Test" - -8,72\%.

В експериментальній групі в кінці дослідження, як і в контрольній, спостерігається поліпшення показників координаційних здібностей. Але, на відміну від контрольної, статистично достовірні відмінності між початковими й кінцевими значеннями було виявлено за результатами всіх тестів, крім координаційно-рухової витривалості ( $>>0,05)$.

Великі позитивні зміни зафіксовано у значеннях тесту на стато-динамічну рівновагу в хлопців експериментальної групи. Підтверджено достовірність змін на високому статистичному рівні $(\mathrm{p}<0,001)$ після закінчення дослідження на $173,39 \%$ і 75,84 \% від вихідного рівня, відповідно. Також відбулося достовірне поліпшення показників "Hexagonal Obstacle Test" (17,4 $\pm 2,3$ i $12,2 \pm$ 0,5 с) на $-29,89 \%$.

Прикінцеві значення контрольної та експериментальної груп вказали на достовірність змін за всіма показниками.

Висновки. Під впливом секційних занять у спортсменів із панкратіону відбулися статистично вірогідні зміни за тестом "Y Balance Test Station" від $\mathrm{p}<0,05$ до $\mathrm{p}<0,001$ після закінчення дослідження. Зокрема, за амплітудою рухів уперед констатовано відносний приріст на 18,52 \% ( $<00,01)$; за амплітудою рухів внутрішньо назад - на 11,26 \% ( $<00,001)$; за амплітудою рухів латерально назад - на 12,5 \% $(\mathrm{p}<0,05)$ від вихідного рівня. У контрольній групі статистично достовірних змін у спортсменів із тхеквондо не зареєстровано $(\mathrm{p}<0,05)$. Засвідчено тенденцію до їх підвищення. Різниця перебувала на рівні статистичної похибки як на початку, так i наприкінці дослідження.

Порівняння прикінцевих значень контрольної та експериментальної груп вказало на високу статистичну значущість $(\mathrm{p}<0,001)$ отриманих показників за амплітудою рухів внутрішньо назад (100,2 $\pm 1,1$ см у контрольній групі та $110,3 \pm 0,3$ см в експериментальній групі) за відносного приросту на 10,08 \%. Виявлено значні позитивні зміни також за амплітудою рухів уперед. Достовірність змін підтверджено на статистичному рівні $\mathrm{p}<0,01$ $(67,9 \pm 3,1$ см і 78,7 $\pm 0,3$ см) за відносного приросту на $15,91 \%$. Також відбулася достовірна різниця $(\mathrm{p}<0,05)$ показників за амплітудою рухів латерально назад на 8,57\%.

\section{ЛІТЕРАТУРА}

1. Thomas R.E., Thomas B.C. Systematic review of injuries in mixed martial arts. The Physician and sports medicine. 2018. № 2 (46). P. 155-167.

2. Apriantono T., Herman I., Winata B., Hasan M., Juniarsyah A., Ihsani S., Hidayat I., Safei I., Hindawan I. Differences of physiological characteristics of taekwondo junior players vs. Pencak Silat junior players. Physical Activity Review. 2020. № 8 (2). P. 9-15.

3. Тищенко В., Лисенчук Г. Инновации в совершенствовании специальной физической подготовки в спортивных единоборствах (современный аспект). Вісник Кам'янеиь-Подільського національного університету імені Івана Огієнка. Фізичне виховання, спорт і здоров'я людини. 2019. Вип. 12. C. $83-87$.

4. Тищенко В., Парлаг Д., Тищенко Д. Удосконалення спеціальної фізичної підготовленості борців вільного стилю на етапі попередньої базової підготовки. Вісник Запорізького нащіонального університету : збірник наук. праць. Фізичне виховання та спорт. Запоріжжя : Запорізький національний університет, 2019. № 1. С. 139-146.

5. Тищенко В., Солоха А. Характерні особливості розвитку сили у кікбоксерів на початковому етапі спортивної підготовки. Вісник Запорізького національного університету. Фізичне виховання та cnopm. Запоріжжя : Запорізький національний університет. 2018. № 2. С. 129-134.

6. Дегтярева Д., Репникова Е. Тай-бо как средство физической подготовки юношей, занимающихся панкратионом. Успехи современной науки. 2016. № 7(1). С. 95-98.

7. Наконечний I. Взаємозв'язок спеціальної фізичної та техніко-тактичної підготовки висококваліфікованих спортсменів з панкратіону. Вісник Прикарпатського університету. Серія : Фізична кульmура. 2020. С. 62-67.

8. Дзорданидис В., Кузьмин В. Анализ соревновательной деятельности панкратионистов. Ученые записки. 2008. № 8 (42). С. 28-31.

9. Коньков Д. Методические особенности построения тренировочного процесса в панкратионе. Известия Российского государственного педагогического университета им. А.И. Гериена. 2008. № 58. С. 399-405.

10. Юхно Ю., Зарудний В., Олексенко І., Журавель А. Состав и структура соревновательной деятельности в панкратионе на современном этапе его развития. Физическое воспитание студентов. 2011. Вып. 4. С. 92-95.

11. Согор О., Пітин М. Показники змагальної діяльності юних спортсменів із панкратіону. Науковий часопис наи. пед. ун-ту ім. М.П. Драгоманова. 2019. № 9 (117). С. 83-89. 
12. Nakonechnyi I., Galan Y. Development of behavioral self-regulation of adolescents in the process of mastering martial arts. Journal of Physical Education and Sport. 2017. T. 17. P. 1002-1008.

13. Панкратіон : навчальна програма для дитячо-юнацьких спортивних шкіл. Київ, 2010. 54 с.

14. Тхеквондо : навчальна програма для дитячо-юнацьких спортивних шкіл. Київ, 2009. 87 с.

\section{REFERENCES}

1. Thomas R.E., Thomas B.C. (2018) Systematic review of injuries in mixed martial arts. The Physician and sports medicine. No 2 (46). P. 155-167. [in English].

2. Apriantono T., Herman I., Winata B., Hasan M., Juniarsyah A., Ihsani S., Hidayat I., Safei I., Hindawan I. (2020) Differences of physiological characteristics of taekwondo junior players vs. Pencak Silat junior players. Physical Activity Review. No 8(2). P. 9-15. [in English].

3. Tyshchenko V., Parlah D., Tyshchenko D. (2019) Udoskonalennya spetsial'noyi fizychnoyi pidhotovlenosti bortsiv vil'noho stylyu na etapi poperedn'oyi bazovoyi pidhotovky [Perfection on the level of special physical readiness of freestyle wrestlers at the stage of preliminary base preparation]. Visnyk Zaporiz'koho natsional'noho universytetu. Fizychne vykhovannya ta sport [Visnyk of Zaporizhzhya National University. Physical education and Sports] (electronic journal). No 1. P. 139-146. [in Ukraine].

4. Tyshchenko V., Solokha A. (2018) Kharakterni osoblyvosti rozvytku syly u kikbokseriv na pochatkovomu etapi sportyvnoyi pidhotovky [Important characteristics to develop kickboxing' strength in the initial stage of sports training]. Visnyk Zaporiz'koho natsional'noho universytetu. Fizychne vykhovannya ta sport [Visnyk of Zaporizhzhya National University. Physical education and Sports] (electronic journal). No 2. P. 129-134. [in Ukraine].

5. Tishchenko V., Lisenchuk G. (2019) Innovatsii v sovershenstvovanii spetsial'noy fizicheskoy podgotovki v sportivnykh yedinoborstvakh (sovremennyy aspekt) [Innovation in enhancing of special physical preparation in martial arts sports (modern aspects)]. Visnyk Kam"yanets'-Podil's'koho natsional'noho universytetu imeni Ivana Ohiyenka. Fizychne vykhovannya, sport i zdorov"ya lyudyny [Visnyk of Kamianets-Podilskyi Ivan Ohiienko National University. Physical education, Sports and human health]. Vol. 12. P. 83-87. [in Russia].

6. Degtyareva D., Repnikova Ye. (2016) Tay-bo kak sredstvo fizicheskoy podgotovki yunoshey, zanimayushchikhsya pankrationom. Uspekhi sovremennoy nauki [Advances in modern science]. No 7(1). P. 95-98. [in Russia].

7. Nakonechniy I. (2020) Vzayemozvyazok spetsialnoi fizichnoi ta tekhniko-taktichnoi pidhotovki visokokvalifikovanikh sportsmeniv z pankrationu [Relationship between special physical and technical-tactical training of highly qualified pankration athletes]. Visnyk Prykarpat's'koho universytetu. Seriya: Fizychna kul'tura [Bulletin of the Precarpathian University. Series: Physical culture]. P. 62-67. DOI: 10.15330/ fcult.33.62-67. [in Ukraine].

8. Dzordanidis V., Kuzmin V. (2008) Analiz sorevnovatelnoy deyatelnosti pankrationistov [Analysis of the competitive activity of pankrationionists]. Uchenyye zapiski [Scientific notes]. No 8 (42). P. $28-31$. [in Russia].

9. Konkov D. (2008) Metodicheskie osobennosti postroeniya trenirovochnoho protsessa v pankratione [Methodological features of the construction of the training process in pankration]. Izvestiya Rossiyskogo gosudarstvennogo pedagogicheskogo universiteta im. A.I. Gertsena [Bulletin of the Russian State Pedagogical University name A.I. Herzen]. No 58. P. 399-405. [in Russia].

10. Yukhno Yu., Zarudniy V., Oleksenko I., Zhuravel A. (2011) Sostav i struktura sorevnovatelnoy deyatelnosti v pankratione na sovremennom etape eho razvitiya [Composition and structure of competitive activity in pankration at the modern stage of its development. Fizicheskoye vospitaniya studentov [Physical education students]. Vol. 4. P. 92-95. [in Russia].

11. Sogor O., Pityn M. (2019) Pokazniki zmahalnoi diyalnosti yunikh sportsmeniv iz pankrationu [Indicators of competitive activity of young athletes in pankration]. Naukovyy chasopys nats. ped. un-tu im. M.P. Drahomanova [Scientific journal of the National Pedagogical University named after MP Drahomanov]. No 9(117). P. 83-89. [in Ukraine].

12. Nakonechnyi I., Galan Y. (2017) Development of behavioral self-regulation of adolescents in the process of mastering martial arts. Journal of Physical Education and Sport. No 17. P. 1002-1008. [in English].

13. Pankration: navchalna prohrama dlya dityacho-yunatskikh sportivnikh shkil (2010) [Pankration: a curriculum for children's and youth sports schools]. Kyiv. [in Ukraine].

14. Taekwondo: navchalna prohrama dlya dityacho-yunatskikh sportivnikh shkil (2009) [Pankration: a curriculum for children's and youth sports schools]. Kyiv. [in Ukraine]. 